\title{
INVESTIGATION OF MIXED METAL SORBENT/CATALYSTS FOR THE SIMULTANEOUS REMOVAL OF SULFUR AND NITROGEN OXIDES
}

GRANT NUMBER: DE-FG22-96PC96216--05

START DATE: September 9, 1996

EXPECTED COMPLETION DATE: August 31, 1999

PRINCIPAL INVESTIGATOR: Ates Akyurtlu

CO-INVESTIGATOR: Jale F. Akyurtlu

Department of Chemical Engineering

Hampton University

Hampton, VA 23668

Semi-Annual Technical

Progress Report

March 1999 


\section{DISCLAIMER}

"This report was prepared as an account of work sponsored by an agency of the United States Government. Neither the United States Government nor any agency thereof, nor any of their employees, makes any warranty, expressed or implied, or assumes any legal liability or responsibility for the accuracy, completeness, or usefulness of any information, apparatus, product, or process disclosed, or represents that its use would not infringe privately owned rights. Reference herein to any specific commercial product, process, or service by trade name, trademark, manufacturer, or otherwise does not necessarily constitute or imply its endorsement, recommendation, or favoring by the United States Government or any agency thereof. The views and opinions of authors expressed herein do not necessarily state or reflect those of the United States Government or any agency thereof." 


\begin{abstract}
Simultaneous removal of $\mathrm{SO}_{2}$ and $\mathrm{NO}_{\mathrm{x}}$ using a regenerable solid sorbent will constitute an important improvement over the use of separate processes for the removal of these two pollutants from stack gases and possibly eliminate several shortcomings of the individual $\mathrm{SO}_{2}$ and $\mathrm{NO}_{\mathrm{x}}$ removal operations. The work done at PETC and the DOE-funded investigation of the investigators on the sulfation and regeneration of aluminasupported cerium oxide sorbents have shown that they can perform well at relatively high temperatures (823-900 K) as regenerable desulfurization sorbents. Survey of the recent literature shows that addition of copper oxide to ceria lowers the sulfation temperature of ceria down to $773 \mathrm{~K}$, sulfated ceriabased sorbents can function as selective SCR catalysts even at elevated temperatures, $\mathrm{SO}_{2}$ can be directly reduced to sulfur by $\mathrm{CO}$ on $\mathrm{CuO}$-ceria catalysts, and ceria-based catalysts may have a potential for selective catalytic reduction of $\mathrm{NO}_{\mathrm{x}}$ by methane. These observations indicate a possibility of developing a ceria-based sorbent/catalyst which can remove both $\mathrm{SO}_{2}$ and $\mathrm{NO}_{\mathrm{x}}$ from flue gases within a relatively wide temperature window, produce significant amounts of elemental sulfur during regeneration, and use methane for the selective catalytic reduction of $\mathrm{NO}_{\mathrm{x}}$.
\end{abstract}

The objective of this research is to conduct kinetic and parametric studies of the selective catalytic reduction of $\mathrm{NO}_{\mathrm{x}}$ with $\mathrm{NH}_{3}$ and $\mathrm{CH}_{4}$ over alumina-supported cerium oxide and copper oxide-cerium oxide sorbent/catalysts; investigate $\mathrm{SO}_{2}$ removal at lower temperatures by supported copper oxide-cerium oxide sorbents; and investigate the possibility of elemental sulfur production during regeneration with $\mathrm{CO}$ or with $\mathrm{CH}_{4}$ air mixtures.

The sorbents consisting of cerium oxide and copper oxide impregnated on alumina have been prepared and characterized. Their sulfation performance has been investigated in a TGA setup, studying mainly the effects of temperature, sorbent composition, metal loading and support type. As a result of the sulfation experiments, a relatively wide temperature window was established for the use of alumina-supported cerium oxide-copper oxide as regenerable sorbents for sulfur dioxide removal. 
In the 723-823 K temperature range, cerium oxide-copper oxide sorbents have specific sorbent capacities (mass of sulfur removed per unit mass of metal sorbent) and sulfation rates significantly higher than those of cerium oxide and copper oxide sorbents used alone. Best sulfation performance was exhibited by the sorbent containing 1:1 molar ratio of cerium and copper. Specific sulfur capacities decreased as the coverage of the support surface by the metal oxides approached monolayer coverage. Sorbents appeared to be resistant to cycling. No loss of sulfation capacity was observed after the third cycle.

Preliminary evaluation of these sorbents for the selective reduction of $\mathrm{NO}_{\mathrm{x}}$ gave promising results with ammonia, but indicated low selectivity when methane was used as a reductant. The catalyst containing equimolar amounts of cerium and copper is not active for $\mathrm{NO}$ reduction by $\mathrm{CH}_{4}$ at low temperatures and is not selective at high temperatures. It is active and selective for $\mathrm{NO}_{2}$ reduction with $\mathrm{CH}_{4}$ at temperatures below $423 \mathrm{~K}$ and it is active and selective for $\mathrm{NO}_{2}$ reduction with $\mathrm{NH}_{3}$ at temperatures $373 \mathrm{~K}$ to $733 \mathrm{~K}$. In the reduction of $\mathrm{NO}$ with $\mathrm{NH}_{3}$, the conversion passes through a maximum at $573 \mathrm{~K}$. Different catalyst compositions and reaction conditions are currently being investigated for the reduction of $\mathrm{NO}$ and $\mathrm{NO}_{2}$ with methane and ammonia. 


\section{TABLE OF CONTENTS}

$\underline{\text { Page }}$

Disclaimer

ii

Abstract

iii

Executive Summary

1

Work Done

3

A) Sulfation 3

I) Effect of Metal Loading 3

II) Results and Discussion 4

III) Conclusions $\quad 6$

B) $\mathrm{NO}_{\mathrm{x}}$ Removal $\quad 6$

I) Experimental $\quad 6$

II) Results and Discussion $\quad 8$

C) Additional Activities $\quad 8$

$\begin{array}{ll}\text { Future Plans } & 9\end{array}$

$\begin{array}{ll}\text { References } & 10\end{array}$

Graphs 1-8 11 


\section{EXECUTIVE SUMMARY}

This research project was proposed in response to the Program Solicitation Number DE-PS2296PC96200 for the support of advanced coal research at U.S. colleges and universities. It is related to the "Technical Topic 6. Environmental Science" cited in the program solicitation and it involves the elimination of gaseous pollutants arising from coal utilization. It is expected that this research will constitute a step in the commercial application of a new technology for the simultaneous removal of $\mathrm{SO}_{2}$ and $\mathrm{NO}_{\mathrm{x}}$.

The objective of this research project is to conduct kinetic and parametric studies of $\mathrm{SCR}$ of $\mathrm{NO}_{\mathrm{x}}$ with $\mathrm{NH}_{3}$ and $\mathrm{CH}_{4}$ over alumina-supported ceria and copper oxide-ceria sorbent/catalysts; investigate $\mathrm{SO}_{2}$ removal at lower temperatures by supported copper oxide-ceria sorbents; and investigate the possibility of elemental sulfur production during regeneration with $\mathrm{CO}$ or with $\mathrm{CH}_{4}$-air mixtures.

The expected contributions from the research are:

$>\quad$ Evaluation of the innovative idea of using supported ceria-based catalysts for the selective reduction of NO with methane and the determination of the kinetic parameters.

$>\quad$ Evaluation of the innovative idea of using methane-air mixtures for direct reduction of $\mathrm{SO}_{2}$ to selectively produce elemental sulfur and the determination of the kinetic parameters.

$>$ Determination of the kinetic parameters for sulfation and regeneration of copper oxide-cerium oxide sorbents at temperatures below $823 \mathrm{~K}$.

The sorbents consisting of cerium oxide and copper oxide impregnated on alumina have been prepared and characterized. Their sulfation performance has been investigated in a TGA setup, studying mainly the effects of temperature, sorbent composition, metal loading and support type. As a result of the sulfation experiments, a relatively wide temperature window was established for the use of alumina-supported cerium oxide-copper oxide as regenerable sorbents for sulfur dioxide removal.

In the 723-823 K temperature range, cerium oxide-copper oxide sorbents have specific sorbent capacities (mass of sulfur removed per unit mass of metal sorbent) and sulfation rates significantly higher than those of 
cerium oxide and copper oxide sorbents used alone. Best sulfation performance was exhibited by the sorbent containing 1:1 molar ratio of cerium and copper. Specific sulfur capacities decreased as the coverage of the support surface by the metal oxides approached monolayer coverage. Sorbents appeared to be resistant to cycling. No loss of sulfation capacity was observed after the third cycle.

Preliminary evaluation of these sorbents for the selective reduction of $\mathrm{NO}_{\mathrm{x}}$ gave promising results with ammonia, but indicated low selectivity when methane was used as a reductant. The catalyst containing equimolar amounts of cerium and copper is not active for $\mathrm{NO}$ reduction by $\mathrm{CH}_{4}$ at low temperatures and is not selective at high temperatures. It is active and selective for $\mathrm{NO}_{2}$ reduction with $\mathrm{CH}_{4}$ at temperatures below $423 \mathrm{~K}$ and it is active and selective for $\mathrm{NO}_{2}$ reduction with $\mathrm{NH}_{3}$ at temperatures $373 \mathrm{~K}$ to $733 \mathrm{~K}$. In the reduction of $\mathrm{NO}$ with $\mathrm{NH}_{3}$, the conversion passes through a maximum at $573 \mathrm{~K}$. Different catalyst compositions and reaction conditions are currently being investigated for the reduction of $\mathrm{NO}$ and $\mathrm{NO}_{2}$ with methane and ammonia. 


\section{WORK DONE}

In this period, the main focus was on the completion of the sulfation experiments to investigate the effect of metal loading and support surface area on sulfation and to proceed with the NO-removal experiments.

\section{A) SULFATION}

\section{I) Effect of Metal Loading}

Table 1. Physical Properties of the Sorbents

\begin{tabular}{|c|c|c|c|c|c|c|c|}
\hline \multirow[t]{2}{*}{ Sorbent } & \multicolumn{2}{|c|}{$\begin{array}{l}\text { Cerium Loading, } \\
\text { mass } \%\end{array}$} & \multicolumn{2}{|c|}{$\begin{array}{c}\text { Copper Loading, } \\
\text { mass } \%\end{array}$} & \multirow{2}{*}{$\begin{array}{l}\text { Nominal } \\
\text { Metal } \\
\text { Loading, } \\
\text { mass \% }\end{array}$} & \multirow[t]{2}{*}{$\begin{array}{l}\text { Surface Area, } \\
\mathrm{m}^{2} / \mathrm{g}\end{array}$} & \multirow[t]{2}{*}{ Support } \\
\hline & Nominal & Actual & Nominal & Actual & & & \\
\hline SOR10-II & 5 & 4.58 & 5 & 5.54 & 10 & 122 & CSS200 \\
\hline SOR10-III & 2.5 & 2.26 & 7.5 & 8.42 & 10 & 134 & CSS200 \\
\hline SOR10-IV & 7.5 & 6.49 & 2.5 & 8 & 10 & 122 & CSS200 \\
\hline SOR 10-V & 2 & 1.90 & 8 & 8.76 & 10 & 130 & CSS200 \\
\hline SOR10-VI & 0 & 0 & 10 & 10.36 & 10 & 105 & CSS200 \\
\hline SOR 10-VII & 10 & 8.84 & 0 & 0 & 10 & 126 & CSS200 \\
\hline SOR 10-VIII & 2 & 1.35 & 8 & 7.52 & 10 & & LD350 \\
\hline SOR 05-I & 1 & 0.99 & 4 & 4.18 & 5 & & CSS200 \\
\hline SOR 08-I & 6 & 5.56 & 2 & 2.01 & 8 & & CSS200 \\
\hline SOR 08-II & 6 & 4.16 & 2 & 2.00 & 8 & & LD350 \\
\hline SOR14.4-I & 10.8 & 7.81 & 3.6 & 3.47 & 14.4 & & LD350 \\
\hline
\end{tabular}

The standard procedure for running a sulfation-regeneration experiment had been described in the previous report. The sulfation experiments were performed in a CAHN instruments TG121 thermal analysis system. The standard sulfation gas composition was $0.3 \% \mathrm{SO}_{2}, 3 \% \mathrm{O}_{2}$, and the balance $\mathrm{N}_{2}$. The gas flow rate was $200 \mathrm{~cm}^{3}(\mathrm{NPT}) / \mathrm{min}$. About $3 \mathrm{mg}$ of sorbent particles in the $75-150 \mu \mathrm{m}$ size range were used in each run. Under these conditions, mass transfer effects were negligible. These runs were performed at $773 \mathrm{~K}$.

Metal loading that corresponds to a monolayer coverage on the ALCOA CSS200 alumina is $8 \%$ by 
mass; the surface area of this alumina is $200 \mathrm{~m}^{2} / \mathrm{gram}$. We have used another type of ALCOA alumina, LD350 with a surface area of $360 \mathrm{~m}^{2} / \mathrm{gram}$. A monolayer on the second support corresponds to about $14.4 \%$ by mass of metal loading.

\section{II) Results and Discussion}

The results of the sulfation experiments on the sorbents in Table 1 are presented in Figures 1-4. The monolayer coverage on the sorbents studied is dependent on the cerium to copper ratio. Figure 1 shows the effect of metal loading for sorbents containing a $\mathrm{Cu} / \mathrm{Ce}$ mass ratio of $4: 1$. Since the conversion plotted on the ordinate is a normalized specific sulfur capacity, it is expected that it will increase with decreasing surface coverage because lower surface coverages provide well-dispersed metal ions and sites available for the formation of surface sulfate species (Centi, et al, 1992). The results shown in Figure 1 confirm this expectation. Curve 1 is for a sorbent with a surface coverage of a little over a monolayer. Curves 2 and 3 are for sorbents having about $60 \%$ and $70 \%$ surface coverages, respectively. The highest conversions are obtained for the sorbent with $60 \%$ coverage. Figure 2 shows the sulfation behavior of the same sorbents at $823 \mathrm{~K}$ as in Figure 1. The behavior is similar to that at $723 \mathrm{~K}$.

Figure 3 shows the effect of metal loading for a sorbent containing a 3:1 Ce/Cu mass ratio. Curve 1 is for a sorbent with a monolayer coverage; curve 3 is for a sorbent which has a metal loading $20 \%$ over monolayer; and curve 2 is for the sorbent with $70 \%$ surface coverage. In this case, the sorbent with the monolayer coverage exhibits the highest sulfur capacity. Since the sorbent in curve 2 has a higher surface area, pore blockage may be causing the conversion to be limited at high sulfation levels. It can be observed that the coverages in excess of a monolayer retard the bulk sulfation of alumina and it appears that the excess ceria, which is expected to be present as microcrystals unassociated with alumina, are not as reactive as the cerium aluminate species present in the monolayer. Also, microparticles of metal oxides form above monolayer coverages; these form bulklike metal sulfates, which inhibit sulfation of sub-surface layers because the specific volume of the sulfates is higher than that of the oxides, which will also result in pore closure. Thus, the metal loading affects the metal oxide crystallite size and the bonding interaction between the metal oxide and the support. Figure 4 shows the sulfation 
behavior of the same sorbents at $823 \mathrm{~K}$ as in Figure 3. The behavior is similar to that at $723 \mathrm{~K}$.

Figures 5 and 6 are the same as the Figures 7 and 8 in the previous semiannual report (October 1998) and are included for the sake of comparison. The results indicate that the best dispersion of the metal oxides corresponds to coverage less than a monolayer with 1:1 molar ratio of copper to cerium.

Table 2. Effects of Temperature and Sorbent Composition on Sulfation

\begin{tabular}{|c|c|c|}
\hline Sorbent & Specific Conversion at $3000 \mathrm{~s}$ & Temperature, $\mathrm{K}$ \\
\hline $\begin{array}{c}\text { SOR10-VI } \\
(10 \% \mathrm{Cu} \text { by mass })\end{array}$ & $\begin{array}{l}0.56 \\
0.65 \\
0.64 \\
0.73 \\
0.66\end{array}$ & $\begin{array}{l}723 \\
748 \\
773 \\
798 \\
823\end{array}$ \\
\hline $\begin{array}{c}\text { SOR 10-IV } \\
(7.5 \% \mathrm{Ce}, 2.5 \% \mathrm{Cu} \text { by mass })\end{array}$ & $\begin{array}{l}1.14 \\
1.16 \\
1.20 \\
1.20 \\
1.19\end{array}$ & $\begin{array}{l}723 \\
748 \\
773 \\
798 \\
823\end{array}$ \\
\hline $\begin{array}{c}\text { SOR10-VII } \\
(10 \% \text { Ce by mass })\end{array}$ & $\begin{array}{l}0.70 \\
1.00 \\
1.25\end{array}$ & $\begin{array}{l}723 \\
773 \\
823\end{array}$ \\
\hline
\end{tabular}

Table 2 indicates that the conversion at 3000 seconds of sulfation for the sorbent containing roughly equimolar amounts of cerium and copper (SOR 10-Iv) is about the same at all temperatures while that of the sorbent containing ceria only (SOR10-VII) increase with temperature due to the increased reaction rate. The conversion at 3000 seconds of the sorbent containing only copper oxide is affected by two phenomena: limitation of copper oxide conversion by chemical equilibrium above $773 \mathrm{~K}$ (copper sulfate decomposition) and the resulting increase in the bulk sulfation of the alumina sites due to the presence of unsulfated copper, which catalyzes the $\mathrm{SO}_{3}$ formation. Above $773 \mathrm{~K}$, the bulk sulfation of alumina effectively stops after 3000 seconds of sulfation. For sorbents with high 
copper content, the conversion curves at different temperatures cross over as the result of the decreasing sulfur capacity of copper and increasing sulfation rate of alumina as the temperature increases. As the coverage is decreased below monolayer, the two regions of sulfation become less distinct and vice versa.

\section{III) Conclusions}

The results presented above indicate that temperature of operation and the cerium/copper ratio of the sorbent should be optimized to achieve the best sulfation performance. Additionally, metal loading below monolayer coverage must be optimized due to the tradeoff between higher sulfation efficiency and larger sorbent amounts needed at lower loadings. These optimization procedures should also take the $\mathrm{NO}_{\mathrm{x}}$ removal activity into consideration.

\section{B) NO $\mathrm{x}_{\mathrm{x}}$ REMOVAL \\ I) Experimental}

For $\mathrm{NO}_{\mathrm{x}}$ removal experiments, 2 grams of the sorbent (particle size of $250-425 \mu \mathrm{m}$ ) is weighed and placed in a quartz microreactor. The reactant gas mixture is prepared from high purity bottled gases without further purification.

\section{Experimental variables in a standard SCR experiment:}

$$
\begin{aligned}
& \text { temperature } \quad=773-973 \mathrm{~K} \\
& \mathrm{NH}_{3} / \mathrm{NO} \text { ratio } \quad=0.5-1.2 \text { or } \quad \mathrm{CH}_{4} / \mathrm{NO} \text { ratio }=0.25-1.0 \\
& \text { concentration of } \mathrm{O}_{2}=0.5-4 \% \\
& \text { concentration of } \mathrm{H}_{2} \mathrm{O}=2-10 \% \\
& \text { concentration of } \mathrm{SO}_{2}=0-5000 \mathrm{ppm} \\
& \text { degree of sulfation of the sorbent; }
\end{aligned}
$$


A typical reactant gas composition is 650-900 ppm NO, 0-250 ppm $\mathrm{NO}_{2}, 3.0 \% \mathrm{O}_{2}, 7 \% \mathrm{H}_{2} \mathrm{O}$, 3500 ppm $\mathrm{CH}_{4}\left(\right.$ or $\left.\mathrm{NH}_{3} / \mathrm{NO}_{\mathrm{x}}=1\right)$, balance He. Experiments were performed with both $\mathrm{CH}_{4}$ and $\mathrm{NH}_{3}$ as the reducing agent.

Gas samples were analyzed using a Varian 3400 Gas Chromatograph for $\mathrm{CO}, \mathrm{CO}_{2}, \mathrm{~N}_{2}$, and $\mathrm{O}_{2}$, and Thermo Environmental Instruments Model $42 \mathrm{H}$ Chemiluminescence $\mathrm{NO}-\mathrm{NO}_{2}-\mathrm{NO}_{\mathrm{x}}$ analyzer for $\mathrm{NO}_{2}$ and $\mathrm{NO}$. To avoid the wet analysis methods for the determination of $\mathrm{NH}_{3}$, a low temperature molybdenum converter was purchased for the chemiluminescence analyzer. In the standard high temperature $\mathrm{NO}_{2}$ to $\mathrm{NO}$ converter, ammonia is also converted to $\mathrm{NO}$ and therefore, is measured as NO, while in the low temperature converter negligible ammonia conversion is expected. Thus, by alternately using the high and low temperature converters, we expected to determine ammonia from the difference in the NO measurements.

Unfortunately the initial experimental measurements gave inconsistent results and did not allow the determination of ammonia as intended. A decision was then made to remove the ammonia from the gas stream before it enters the chemiluminescence unit by absorption and then determine the ammonia by titration. We also checked the operation of both the low temperature and the high temperature converters. Further inconsistencies were observed in the $\mathrm{NO}$ and $\mathrm{NO}_{2}$ measurements. This led us to open up the low temperature converter to find the cause of the faulty measurements. It was then noticed that the $\mathrm{NO} / \mathrm{NO}_{2}$ switch on the instrument was connected wrong and the $\mathrm{NO}$ readings indicated $\mathrm{NO}_{2}$, and $\mathrm{NO}_{2}$ readings indicated $\mathrm{NO}$. At this point the solenoid valve in the unit burned out and we did not have the opportunity to repeat the ammonia measurements. Currently we are waiting for the part to be shipped from the manufacturer.

The results reported in the following section were obtained using the high temperature reactor and therefore are only rough estimates. In the calculation of conversions, since at the reactor exit for full $\mathrm{NO}_{2}$ conversion the amounts of $\mathrm{NO}$ and $\mathrm{NO}_{\mathrm{x}}$ were roughly equal, it was assumed that the amount of ammonia at the reactor exit was negligible and the difference between the $\mathrm{NO}_{\mathrm{x}}$ and $\mathrm{NO}$ measured at the reactor inlet was due to both $\mathrm{NO}_{2}$ and $\mathrm{NH}_{3}$. 


\section{II) Results and Discussion}

The results of some $\mathrm{NO}_{\mathrm{x}}$ removal experiments are presented in Figures 7 and 8 . The following conclusions may be drawn from these results:

1. The catalyst containing equimolar amounts of cerium and copper is not active for NO reduction by $\mathrm{CH}_{4}$ at low temperatures and is not selective at high temperatures.

2. The catalyst is active and selective for $\mathrm{NO}_{2}$ reduction with $\mathrm{CH}_{4}$ at temperatures below 423 K.

3. The catalyst is active and selective for $\mathrm{NO}_{2}$ reduction with $\mathrm{NH}_{3}$ at temperatures between 373 to $733 \mathrm{~K}$.

4. In the reduction of $\mathrm{NO}$ with $\mathrm{NH}_{3}$, the conversion passes through a maximum at $573 \mathrm{~K}$.

Since it is planned to use sulfated sorbents as $\mathrm{NO}_{\mathrm{x}}$ removal catalysts, some sorbents were sulfated and sent to a local laboratory for sulfur analysis as reported in the last report. However, the results of the sulfur analysis were not dependable. Now, we are in the process of sending the samples to ALCOA for sulfur analysis. Based on these results, sorbent/catalysts sulfated to different extents will be prepared for $\mathrm{NO}_{\mathrm{x}}$ removal experiments. In the preliminary experiments reported above the behavior of the sulfated catalysts were very similar to that of the oxide catalysts.

\section{C) ADDITIONAL ACTIVITIES:}

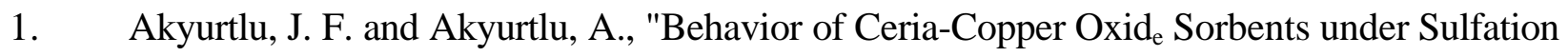
Conditions", accepted for publication at Chem. Eng. Sci. (ISCRE Issue), December 1998.

2. "Behavior of Supported Ceria/CuO Sorbents under Sulfation Conditions" presented at Session 62 of the 2nd World Congress on Environment to be held at Miami, FL in November 15-19, 1998. 
3. "Investigation of Supported Ceria-Copper Oxide Sorbents for the Removal of $\mathrm{SO}_{2}$ and $\mathrm{NO}_{\mathrm{x}}$ from Flue Gases" presented at the DOE 1999 Seventh Annual Historically Black Colleges and Universities and Other Minority Institutions, Miami, FL, March 16-18, 1999.

4. "Catalytic Reduction of Nitrogen Oxides by Methane over Supported Ceria-Copper Oxide Sorbents" accepted for poster presentation at the 16th North American Catalysis Society Meeting to be held at Boston, MA on May 30- June 4, 1999.

\section{FUTURE PLANS}

In the next six months, it is planned:

1. to complete the SCR studies with all the prepared catalyst samples at different temperatures and gas compositions;

2. to complete the characterization of all sorbents, including surface analysis by XRD by ALCOA;

3. to complete the modeling of sulfation reaction on mixed metal oxides;

4. to investigate the regeneration of sorbent with $\mathrm{CO}$ and the possibility of elemental sulfur production;

5. to evaluate all the data;

6. to write the final report. 


\section{REFERENCES}

1. Centi, G., Passarini, N., Perathoner, S., and Riva, A. (1992), "Combined $\mathrm{DeSO}_{2} / \mathrm{DeNO}_{\mathrm{x}}$ Reactions on a Copper on Alumina Sorbent/Catalyst-1. Mechanism of $\mathrm{SO}_{2}$ OxidationAdsorption", Industrial and Engineering Chemistry Research, 31, 1947-1955. 
Figure 1. Effect of Metal Loading at $723 \mathrm{~K}$. Ce/Cu mass ratio $=1: 4$

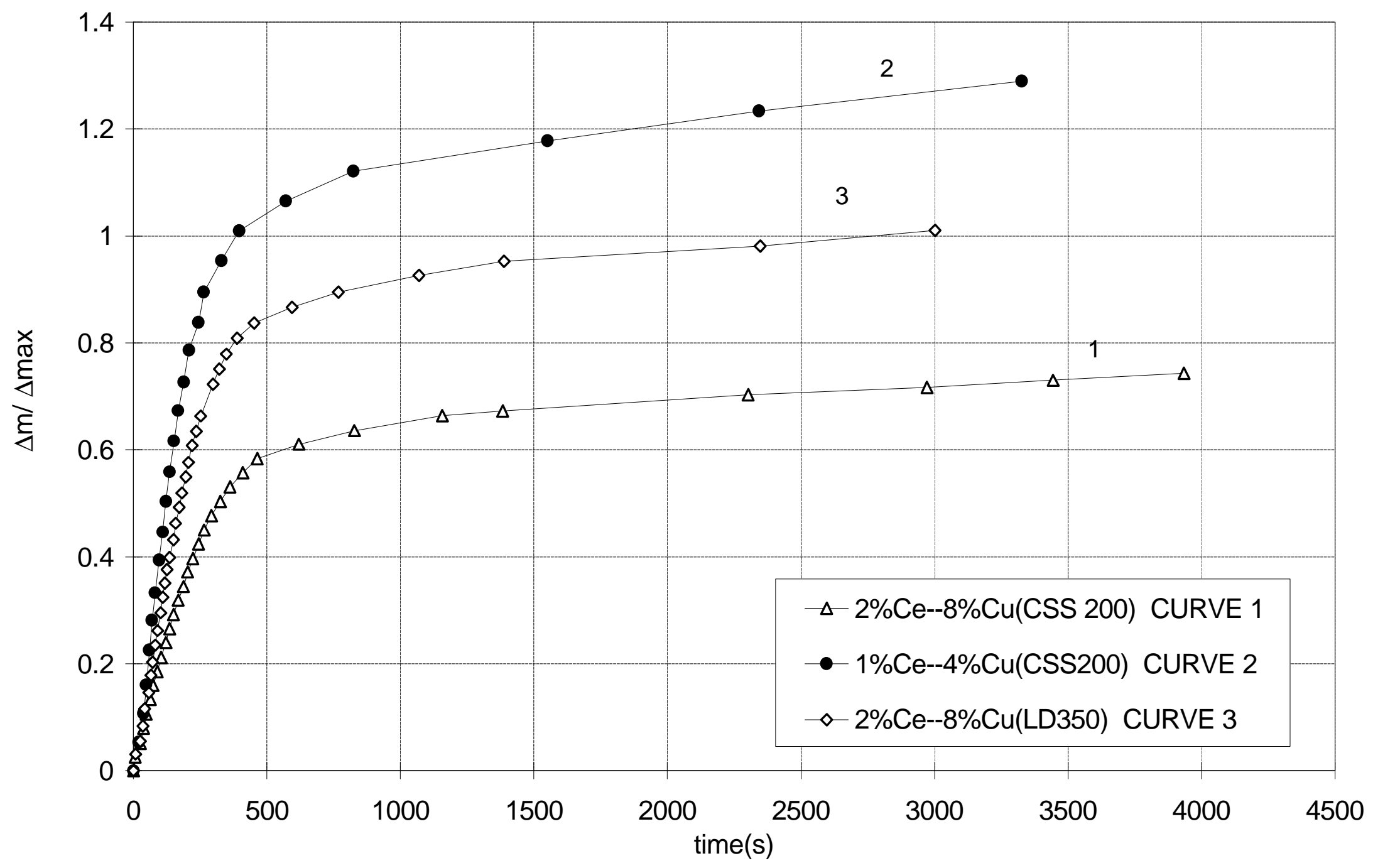


Figure 2. Effect of Metal loading on Sulfation @ 823K

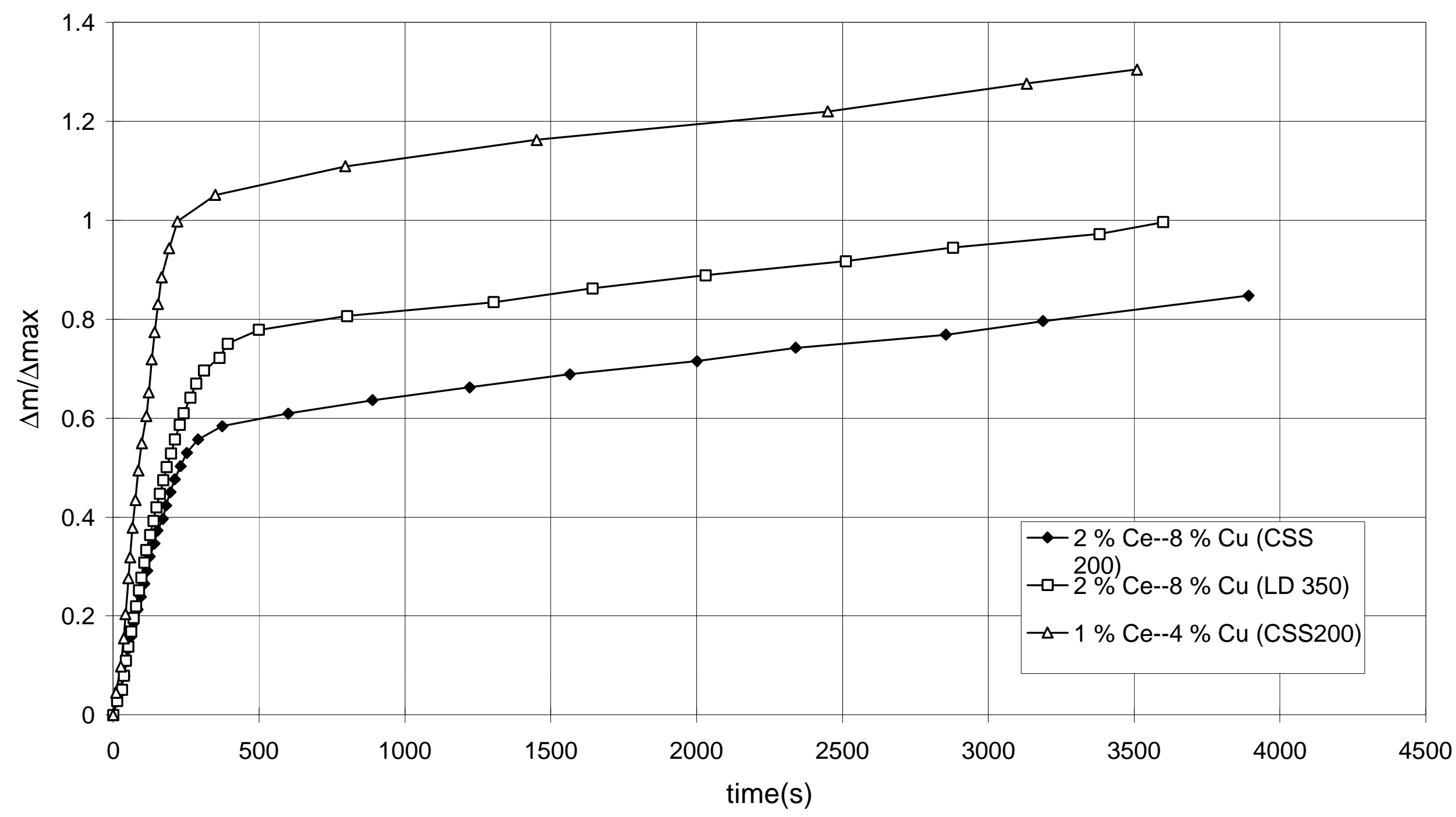


Figure 3. Effect of Metal Loading at $723 \mathrm{~K}$. Ce/Cu mass ratio $=3: 1$

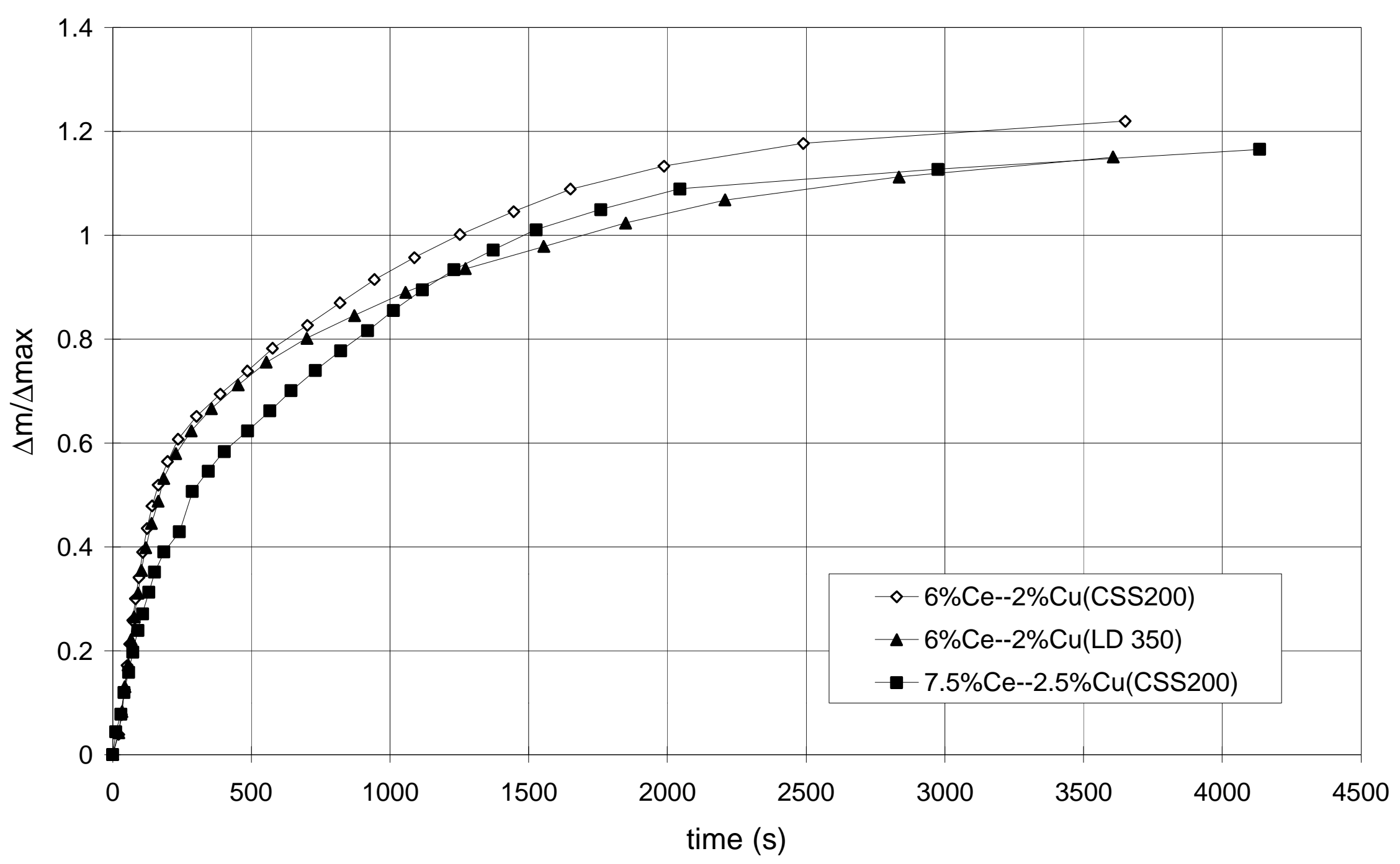


Figure 4. Effect of Metal Loading on Sulfation @ 823K

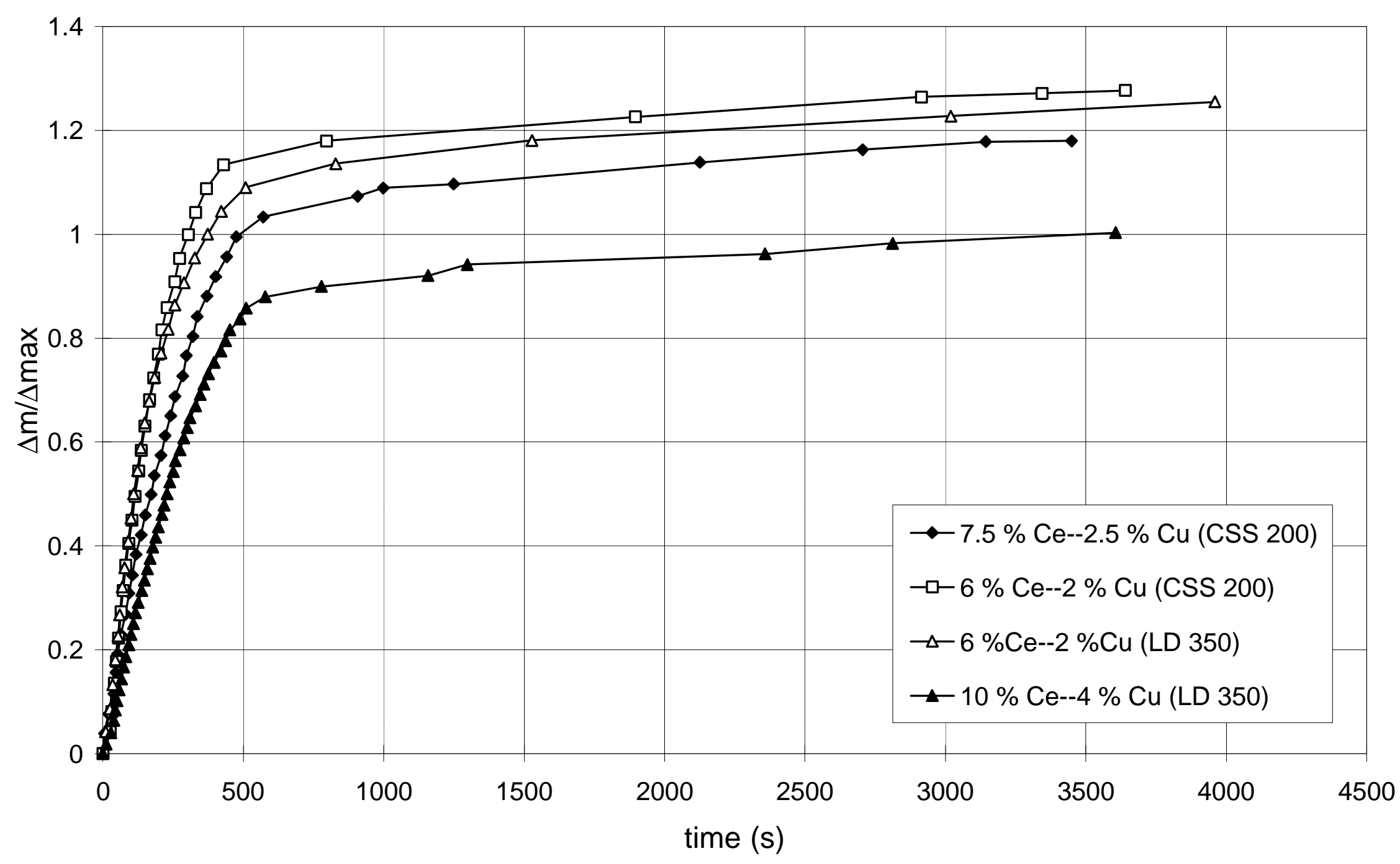


Figure 5. Effect of Sorbent Composition on the Sulfation Behavior at $823 \mathrm{~K}$

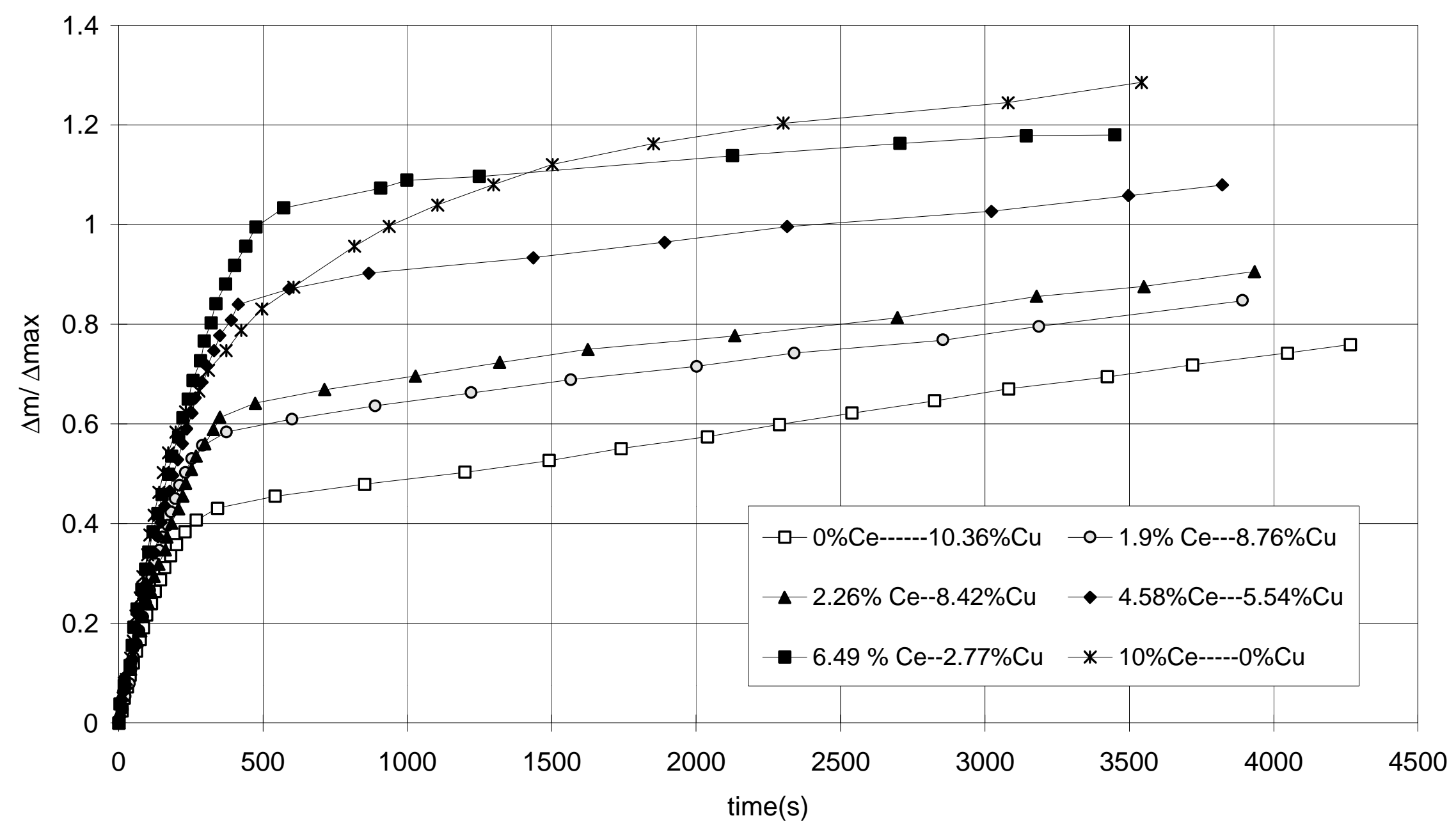


Figure 6. Effect of sorbent composition on sulfation behavior at $723 \mathrm{~K}$

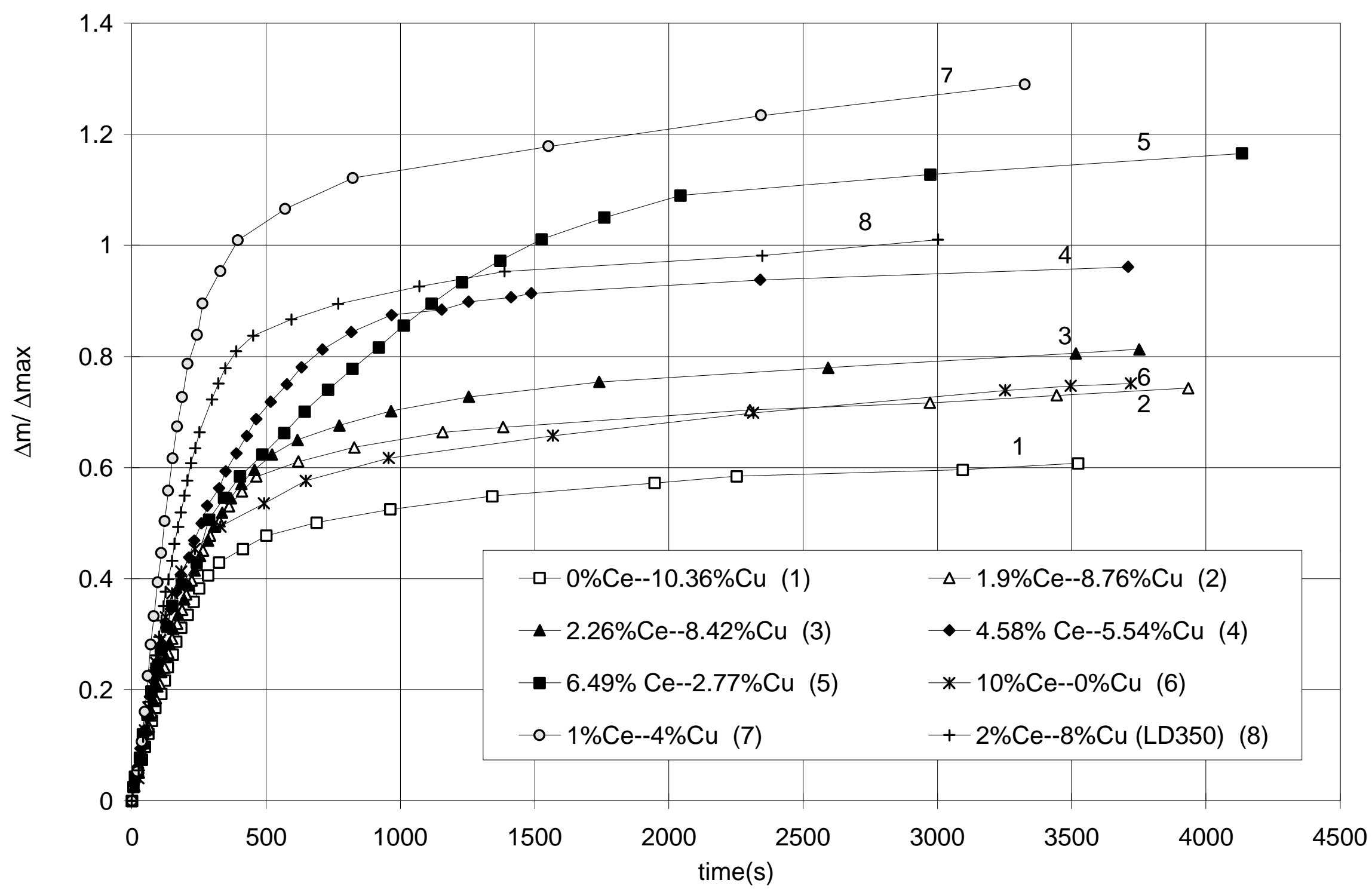


Figure 7. $\mathrm{NO}_{2}$ Conversion by $\mathrm{CH}_{4}$ on Sulfated Catalyst $(\mathrm{Ce} / \mathrm{Cu}=3)$

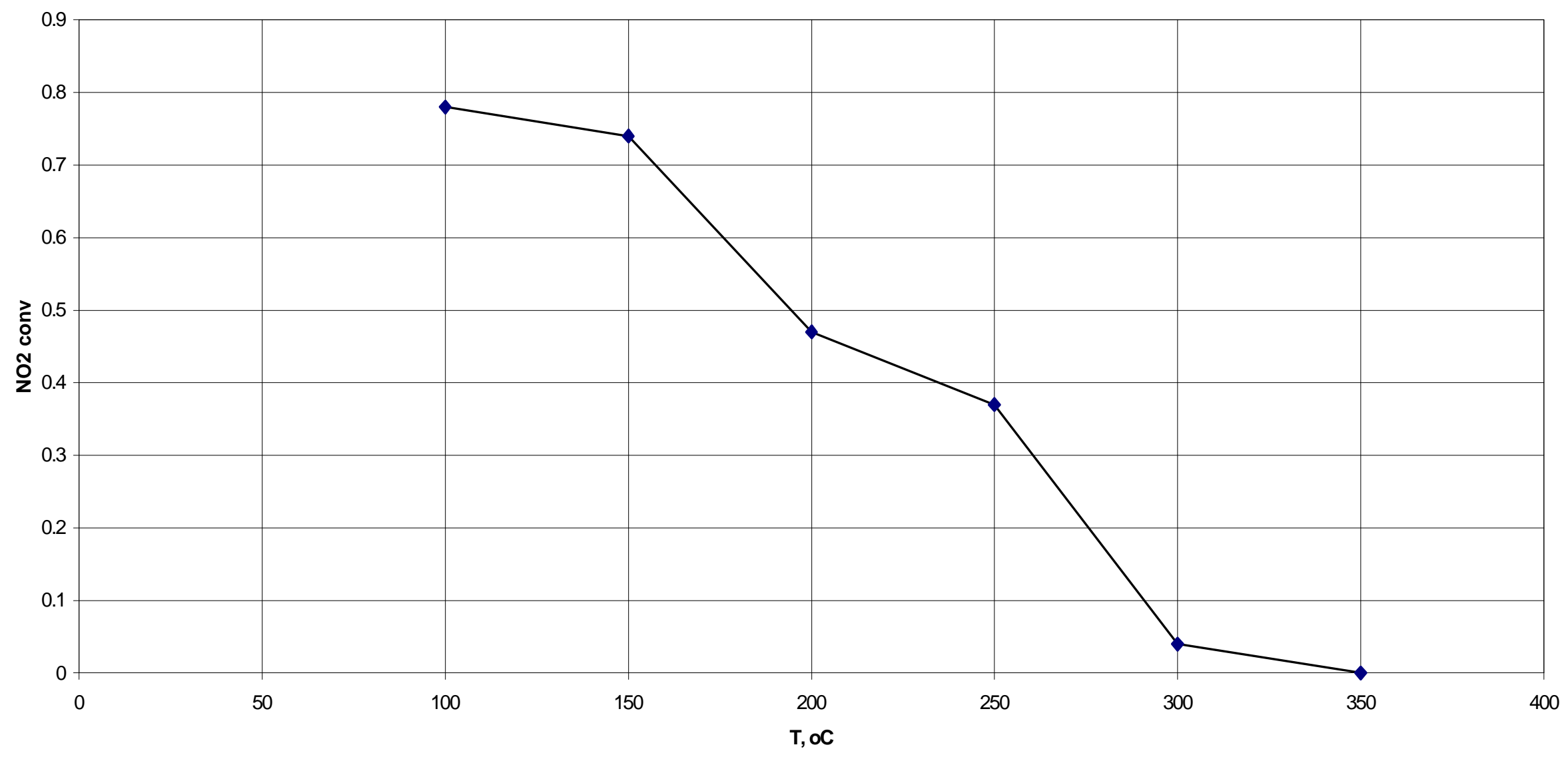


Figure 8. No2 Conversion by NH3 on Sulfated Catalyst $(\mathrm{Ce} / \mathrm{Cu}=3)$

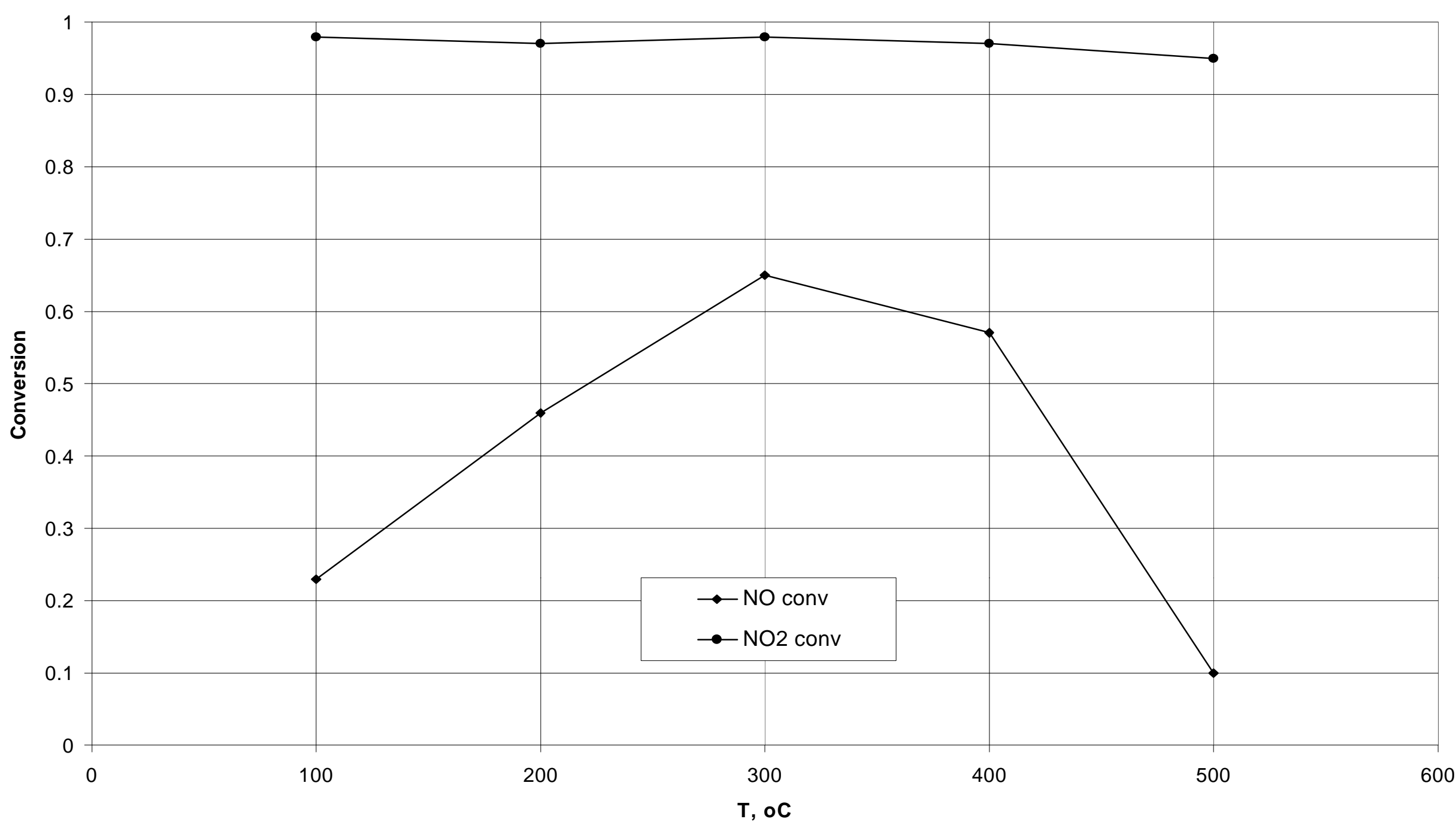

